MedieKultur | Journal of media and communication research | ISSN 1901-9726

Article - Theme section

\title{
Using Bourdieu in Critical Mediatization Research: Communicational Doxa and Osmotic Pressures in the Field of UN Organizations
}

\section{André Jansson}

MedieKultur 2015, 58, 13-29

Published by SMID | Society of Media researchers In Denmark | www.smid.dk The online version of this text can be found open access at www.mediekultur.dk

This article develops a Bourdieusian approach to mediatization. It is argued that the Bourdieusian theories of doxa and fields can make valuable contributions to a critical perspective on mediatization, one that moves beyond the divides between institutionalist, social-constructivist and materialist understandings (e.g., Bourdieu, 1972/1977). Mediatization is here seen as the historically growing dependence on media technologies and institutions within diverse social fields and settings. In order to establish the link between mediatization and Bourdieu's theories (ibid.), the article introduces the concept of communicational doxa, which refers to the taken for granted communicational conventions and demands that regulate the inclusion of membership within a particular field. The article also shows how communicational doxa can be applied as an analytical concept. Findings from qualitative fieldwork carried out among highly mobile and skilled professionals within the field of UN organizations in Geneva, show how the autonomy of social agents is negotiated in relation to an increasingly mediatized communicational doxa.

\section{Keywords}

Bourdieu, mediatization, doxa, mobility, social fields, symbolic power 


\section{Introduction}

Mediatization can be seen as a long-term process of social change, grounded in the ongoing adaptation among social actors and institutions to altered forms of mediation (see, e.g., Couldry and Hepp, 2013; Lundby, 2014). Still, there is a more general problem of specification in mediatization research, pertaining to when a certain type of social transformation is actually to be viewed as an expression of mediatization. On the one hand, the problem lies in the difficulties of unpacking the relationships between media and other social forces, which together mould the logic of practice within different social fields and environments (see Hepp, 2012; Jansson, forthcoming). On the other hand, the problem has to do with the difficulties in establishing the limits of when a certain type of "media invoked" change is substantial and enduring enough to qualify as an instance of mediatization. These two problems must be solved if we want to assess mediatization through empirical inquiry and therefore engage in a meaningful discussion of mediatization. Whereas recent debates around the concept have contributed to a deeper insight and a broader consensus regarding the general nature of mediatization as a meta-process (Krotz, 2007), the increasing popularity of the term has also led to a muddled set of assumptions with regards to its usage. All too often, the concept refers to nothing more than the steadily growing number of technologies and institutions of mediation.

This article is a response to these challenges. Firstly, I want to introduce a critical approach to mediatization, where mediatization is seen as the growing dependence on media technologies and institutions within realms of society that were previously not dependent on media (see also Jansson, 2013a). Such transformations occur both on the institutional level and in everyday life, and can take on three principal forms: functional, transactional and ritual dependence. A common denominator for all instances of mediatization is that they involve negotiations, and as a result, ultimately decrease autonomy on the part of social agents, institutions or fields.

Secondly, I will combine this critical approach with Bourdieu's theory of social fields (see, e.g., Bourdieu, 1972/1977). In order to understand the ways in which various media dependences take shape and how their social consequences unfold, we need to study these phenomena in a situated and contextualized manner. Bourdieu's conceptual apparatus, notably his notion of doxa, provides a comprehensive platform for making sense of how the naturalization of various media technologies and practices is conditioned by pre-existing rules and resources within a given field, while at the same time representing a potential threat to these rules and resources. In order to establish the link between mediatization and Bourdieu's field theory I elaborate the concept of communicational doxa, which refers to the taken for granted communicational conventions and demands (including media practices) that regulate what it takes to be(come) a member of the field.

The amalgamation of Bourdieusian theory and critical mediatization research, I argue, is a way of unveiling, on the one hand, the socio-culturally moulded character of mediatization processes, and, on the other hand, the concrete consequences that media techno- 
logical alterations may have upon long established patterns of communicative practice. The orientation of the present article is therefore mainly theoretical. However, in order to substantiate the theoretical points, in the final section I apply the conceptual framework for analyzing material from qualitative fieldwork, carried out among Scandinavian expatriates occupying qualified positions in UN organizations. I point especially to how their autonomy as social agents within a transnational, yet rather clearly demarcated social field, is negotiated in relation to contemporary, transmedia induced forms of mediatization. Whereas the doxa of UN organizations in certain respects fuels mediatization processes, this development may also involve the long-term corrosion of the boundaries and distinctiveness of the field. I call this phenomenon "osmotic pressures," pointing to how the communicational doxa of the field expands into the (semi-)private spheres of social agents, whose everyday appropriations of new transmedia technologies and applications are in turn influencing the field and its doxa. The case study thus underscores the importance of gaining deeper and culturally situated understandings of social fields, in order to explain how the contradictory forces of mediatization evolve, and how they affect various groups in their everyday life.

\section{A critical perspective on mediatization}

In recent debates around mediatization we have witnessed the consolidation of two main perspectives: the institutionalist and the social-constructivist (Couldry and Hepp, 2013). The institutionalist approach is concerned with how certain institutions in society, such as politics (e.g., Esser and Strömbäck, 2014), religion (e.g., Hjarvard, 2014) and corporate business (e.g., Ihlen and Pallas, 2014), adapt to the logics of dominant media institutions, notably mainstream journalism and commercial broadcasting (see also Hjarvard, 2014). The social constructivist (or culturalist) approach focuses on how the media and their representations, understood in a more complex sense, play into the ongoing constructions of social worlds (Hepp, 2009; Krotz, 2007). In addition to these two perspectives, one can also discern a third perspective, which may be called materialist (or "material"). As Knut Lundby (2014) points out in his introduction to Mediatization of Communication, the materialist perspective is to some extent influenced by the media ecological theories developed by the Toronto School, meaning that the media are seen as material resources whose affordances, or biases (Innis, 1951), set limits to and give opportunities for various forms of social and cultural agency (see Jansson, 2014). Scholars like David Morley (2009) and Shaun Moores (2012), who have argued for a materialist, non-media-centric media studies, are also related to the materialist approach, but do not subscribe directly to the term mediatization.

There is, however, a specific feature of the mediatization concept that has not been sufficiently elaborated in the debate so far, namely, its critical potential. Conceiving of mediatization as an essentially critical concept, I argue, sharpens all three of the abovementioned perspectives. The critical perspective actualizes how other social processes, in a broad vari- 
ety of domains, and at different levels, become inseparable from and ultimately dependent on technological processes and resources of mediation. Speaking of dependence is a way of ensuring that mediatization refers to something more specific than simply the increasing use or saturation of media in various realms of society, or the quantitative growth in circulation of data and information. In my view, the concept of mediatization should be reserved for those qualitative shifts in socio-material relations whereby certain increases in the human capacity for material, social or cultural activity that are enabled by media, also incorporate a decrease in individual or institutional autonomy. This in turn, means that mediatization necessarily implies a state of growing contradiction, which ultimately boils down to the opposition between autonomy and dependence.

This position can be illustrated by the well-known tension between McLuhan's (1964) notion of media as "the extensions of man" and Williams' (1974) elaboration of media as cultural form. Whereas McLuhan predominantly focused on the capabilities of media technologies for overcoming various material restraints and shaping human behaviour, Williams emphasized how the significance of any new media is not technologically pre-determined, but shaped into place by cultural forces in different contexts. My point is that we can only speak of mediatization in cases where media are thoroughly integrated in cultural environments as part of "common practice," that is, when they occupy the status of intersubjectively shared cultural forms. This means that their meanings and conditions of use are more or less taken for granted and that they, to a greater or lesser extent, are seen as indispensable for maintaining regular activities within a certain sector of social life (Jansson, 2014). However, this focus on media as cultural form does not implicate a dismissal of all points advocated by medium theorists. It goes without saying that the type of dependencies that take shape in various socio-cultural contexts cannot be understood in isolation from the basic possibilities that new media provide as technics (Ihde, 1990), such as extended portability or interactivity. This again points to the fact that mediatization materializes through mutual processes of moulding (cf. Hepp, 2012; Jansson, forthcoming).

What do I mean when I say that mediatization always implies a negotiation of autonomy? One may of course argue that media (understood as technologies and institutions) in many ways extend the capabilities of agents and institutions (Schulz, 2004), thus contributing to the strengthening of their autonomy. The internet has made it possible for anyone to search for potentially liberating information, to an extent that is historically unprecedented. Mobile devices have lowered the threshold for many people to become mobile, to feel safe and secure when they move about in environments near and afar. But at the same time the growing reliance on media for keeping informed, staying in touch, and carrying out various transactions, ties individuals and institutions closer to the technological infrastructures and institutional logics of media. This is what Giddens (1991) refers to when he discusses the growing necessity of trust in abstract systems. This is where negotiations of autonomy occur. 
To make this point clearer, we can distinguish between three ideal types (or levels) of dependence. Firstly, there is functional media dependence. This type of dependence emerges when practical procedures are altered and made dependent on mediated forms of communication, to the extent that a certain activity can no longer be carried out without the assistance of media. Kitchin and Dodge (2011), for example, show how the very constitution of many modern spaces that people are accustomed to interacting with(in), rely on software monitored processes. One example is the modern supermarket. If the computerized infrastructures for making purchases would crash, shopping would be impossible (since staff can no longer process goods manually), and the supermarket (ultimately defined as a code/space) would cease to be a supermarket.

Secondly, there is transactional dependence, which refers to conditions where social actors comply with the rules and regulations set up by the media, technologically or institutionally, in order to achieve a certain good. This is typically the case when we speak of the mediatization of politics, where politicians give up some of their autonomy in order to reach media exposure (e.g., Schulz, 2004). It is also a common feature of today's commercialized forms of surveillance where individuals sacrifice a certain share of their privacy, giving away personal information, in order to take advantage of various online service benefits (e.g., Andrejevic, 2014).

Finally, we come to ritual dependence. This type of dependence is more difficult to delimit since it is based on the socio-cultural power of shared routines. It means that the possession of certain media technologies is seen as mandatory within a given socio-cultural setting, and that certain ways of using media become normalized as "standard procedure." Think of the routinized ways in which many groups use Facebook and other social media for sharing information with their peers, or the regular use of PowerPoint slides in work-related presentations, even though neither of these forms of communication are institutionally imposed or defined as functionally mandatory. Rather, they can be seen as adaptations to social expectations, and the successively evolving cultural order of things.

These three types of media dependence constitute a hierarchical order of accentuated indispensability (functional dependence being the most cohesive form). In real-life settings they are often interwoven: for example, ritual dependences often involve moments of transaction, and functional dependences are more often than not bound up with particular rituals and/or routines. Again, it is crucial to keep in mind that it is not the media as such that create these dependences, but the different social, cultural, economic, and political forces that ultimately define what media should be used for and in what ways, i.e., the cultural form of media (Williams, 1974). This categorization has the advantage of cutting across the abovementioned approaches to mediatization, showing that the critical perspective enables us to explore overarching questions about how mediatization affects the constitution of power and domination in various realms of society. Furthermore, the inherently dialectical and continuously contested relationship between social autonomy and media dependence regarding agents, institutions and fields, gives us a valid entry point 
for building a bridge between Bourdieusian field theory and mediatization research. Within a particular field, one may identify media dependences that are of a functional, transactional, as well as ritual nature.

\section{Media dependence and communicational doxa}

There have been relatively few attempts to elaborate Bourdieusian theory for understanding mediatization, and even fewer arguments as to the validity of mediatization as a concept that could add value to the Bourdieusian framework. The most interesting attempt so far is Couldry's (2003a) analysis of the media as a meta-field occupying a status similar to the state as described by Bourdieu (e.g., Bourdieu and Wacquant, 1992: 110-5; Bourdieu, 1996). From such a viewpoint, the operations of media institutions and their agents should not be analyzed principally in terms of a distinct logic and form of capital ("media capital"), comparable to those defining specialized fields like art, literature and academia. Rather, the media should be seen as conveyors of meta-capital that cuts across and contributes to the legitimation of more specialized fields. Couldry suggests that:

\footnotetext{
the media's meta-capital over specific fields might operate in two distinct ways: first, as Bourdieu explicitly suggests for the state, by influencing what counts as capital in each field; and second, through the media's legitimation of influential representations of, and categories for understanding, the social world that, because of their generality, are available to be taken up in the specific conflicts in any particular field. (Couldry, 2003a: 668, italics in original)
}

As a case in point, Couldry discusses the growing importance of media exposure and image creation that permeates a number of social fields today.

This line of thinking has more recently (and logically, I believe), led Couldry (2014) to integrate the notion of media meta-capital within a theory of mediatization. As he argues, there are good reasons to conceive of mediatization as a meta-process that operates in non-linear and transversal ways, meaning that it exercises different kinds of influence within different fields, depending on how media meta-capital affects the circulation and legitimation of specific forms of capital. This perspective grants us a sensitizing approach that moves away from the more reductive understandings of "media logics," which tend to fall short when it comes to making sense of the manifold and fluctuating appearances of mediatization in different areas of social space.

Still, Couldry's perspective shares some of the problems of the institutionalist paradigm. His focus is on media-as-institutions (i.e., the media) and their influences in terms of symbolic power. The same thing can be said about other recent efforts to integrate Bourdieusian theory within mediatization research, such as Rawolle's and Lingard's $(2010,2014)$ recent analyses of the mediatization of educational policies. Their main concern is to chart out the media's privileged position in shaping dominant discourses of the world, and by extension the logics of fields and worldviews of ordinary citizens (see also Couldry, 2003b). In compari- 
son to the state, however, the media (and thus mediatization), represent much more than such symbolic-institutional processes as world description, prescription and legitimation. In particular, the media attain a material appearance in the lives of social agents, in the shape of continuously evolving technologies-as-properties that form the basis for, and amalgamate with, different kinds of social and cultural agency. The notion of "media meta-capital" is thus valid only within confined areas of what we may refer to as "the media," namely those institutionalized areas that show some resemblance with the state.

Without disregarding the value of earlier institutionalist attempts to link together Bourdieu and mediatization theory, I wish to introduce a more holistic and practice-based perspective here, one which relates mediatization to the structural dynamics of everyday life as charted, for instance, in Bourdieu's (1979/1984) work on cultural taste and distinction. I will discuss mediatization in terms of the normalized and growing indispensability of media as cultural forms within the internal logics of fields, as well as their expansion into associated realms of social life (Williams, 1974). Linking this to the critical perspective outlined above, I will assess how the integration of media within field-specific doxa, influences the dialectical relationship between autonomy and dependence at the profound level of everyday practice.

The concept of doxa can be traced to Husserlian phenomenological theory and its understanding of the lifeworld as an intersubjective realm of taken-for-grantedness (see, e.g., Schutz, 1962; Schutz and Luckmann, 1973). Doxa is the shared principles and norms of practice that keep communities together, making their members act in predictable ways that reproduce the order of the lifeworld. Doxa is therefore a source of social security, granting a sense of belonging and placement as long as the individual adheres to the established order. Accordingly, doxa invokes restrictions to the autonomy of social agents through consent rather than direct force, mediating "the dialectic of objective changes and the agents' aspirations, out of which arises a sense of limits, commonly called the sense of reality" (Bourdieu, 1972/1977: 164). Bourdieu's appropriation of doxa consequently leads us to problematize the ways in which social power-relations are maintained, and evolve as a normalized and broadly accepted order of things,

We need thoroughly to sociologize the phenomenological analysis of doxa as an uncontested acceptance of the daily lifeworld [...] when it realizes itself in certain social positions, among the dominated in particular, it represents the most radical form of acceptance of the world, the most absolute form of conservatism. This relation of prereflexive acceptance of the world grounded in a fundamental belief in the immediacy of the structures of the Lebenswelt represents the ultimate form of conservatism. (Bourdieu and Wacquant, 1992: 73-4)

To act and relate to the world in "the doxic mode" is a matter of submitting to the rules, relationships and classificatory structures that constitute the social world of which one is already part. It is a matter of accepting that one's autonomy as social agent is based on the very recognition of one's propensity to act in line with doxa, thus reproducing the very order that is a necessity for one's status as social agent. We can see this mechanism 
played out in everyday life, through the social sanctions that strike those who transcend the boundaries of what is acceptable, or through the unease felt by those who enter social arenas in which they do not belong. However, when analysing the workings of social fields, it becomes even more relevant to consider those whose nature is in a clearer sense defined by "the rules of the game," and the circulation of specific forms of capital. As Bourdieu points out in a discussion of the artistic field, the autonomy of individual agents can only be granted as long as these agents act within the doxic confines of the field, and thus submit to the preservation of its "purity" and difference in relation to other fields:

\begin{abstract}
Thus we discover that the autonomy acquired by artists, originally dependent for both the content and the form of their work, implied a submission to necessity: artists had made a virtue out of necessity by arrogating to themselves the absolute mastery of the form, but at the cost of no less absolute renunciation of function. As soon as they want to fulfil a function other than that assigned to them by the field, i.e., the function which consists in exercising no social function ("art for art's sake"), they rediscover the limits of their autonomy. (Bourdieu and Wacquant, 1992: 110)
\end{abstract}

The autonomy granted by a field is thus conditioned and ultimately an illusion, established through the abovementioned dialectic between objective reality and aspirations. Autonomy only remains as long as agents put their belief into the ordered arbitrariness of doxa and continue to make investments in the field through conformist practice. Bourdieu's special term for this type of belief is illusio, which is to be veiwed not as an order of reflexivity, he argues, "but of action, routine, things that are done, and that are done because they are things that one does and that have always been done that way" (Bourdieu, 1997/2000: 102). Illusio is the embodied sense of doing the right thing and being in the right place, thus grounding a tacit adherence to doxa.

I will now return to the question of media and communication. In the context of world making and field maintenance, practices of communication can be seen basically as another instance of "things that one does," but which cannot be done in whatever fashion without jeopardizing one's membership of a community or a field. I therefore suggest that we think of communicational doxa as a sub-category of doxa that prescribes the ways in which social agents should communicate with one another, within and across fields, and with what media (understood as the means of communication (see Williams, 1974)). There are, in Bourdieu's work, many examples of the importance of communicative manners and how they are unconsciously adjusted to the requirements of doxa. He mentions the correction of accents when speaking to persons of higher rank, and the choosing of appropriate language in multi-lingual situations (e.g., Bourdieu, 1997/2000: 184; see also Goffman, 1959). Furthermore, in his seminal work Distinction, Bourdieu (1979/1984) unveils an entire universe of unspoken rules that govern which means of communication (magazines, newspapers, television programmes, etc.) different class fractions prefer, or find necessary to appropriate. The fact that communication is part of doxa, means that it attains classifica- 
tory power in a dual sense: on the one hand, through the classification of various goods and practices that are associated with the field (normally in the doxic, conservative mode), and on the other hand, through the self-classifying recognition of, and submission to, doxa itself.

Through these preliminary statements on communicational doxa, it is possible to bring forth a Bourdieusian understanding of mediatization. If we define mediatization as a metaprocess that comes to expression through the taken for granted indispensability of, and adaption to, technologies and institutions of mediation, the connection to communicational doxa is not far-fetched. When media become integrated in doxa it means precisely that they enter the realm of taken for granted order and necessity. The ways in which agents relate to hands-on technological features as well as institutionalized media logics then seem natural and attuned with the general expectations of doxa. A key advantage of conceiving of mediatization in this way, is that the appropriation of "media" is seen as interwoven with, and inseparable from, social and cultural processes at large. The media are woven into the prescribed ways of doing things, which means that their meanings are also moulded through doxa.

Speaking of "media dependence," then, does not refer to a type of dependence that is in any way "natural" or objectively linked to the media as such. Rather, it seems natural precisely because social agents put their belief into doxa, that is, illusio, in order to maintain a sense of autonomy. Doxa functions as a legitimation of media dependence under the auspices of granting further autonomy to those agents who consent with the communicational doxa of the field.

What we arrive at is a view of mediatization that is not restricted to the symbolic power of media institutions, but takes into account the materiality of media. It brings into light what Silverstone (1994) famously called the double articulation of media (see also Livingstone, 2007). I would even argue, in line with Hartmann (2006), that we might speak of a triple articulation, meaning that media become part of communicational doxa in three different shapes (see Jansson, 2014), which can furthermore be linked to the above mentioned three levels of dependence. Firstly, they are integrated as technics. This means, following Ihde's (1990) post-phenomenology, that they become indispensable in their capacity of establishing certain relations between the individual and the world, such as embodiment relations (extensions) and hermeneutic relations (representations). In this form, the media therefore give rise to functional dependences. Secondly, media may become part of doxa as properties, that is, as classified and classifying symbolic markers that are seen as required possessions for expressing the identity of an institution or agent. Here, we are able to identify socially and culturally constructed transactional dependences. Thirdly, the interweaving of media practices and doxa creates dependences through texture. This means that media become an integrated part of the taken for granted material environment and temporal rhythms of everyday life, which normalize certain expectations of positionality and regularity with regards to media practices. This is also where we reach the level of ritual dependence. 
The analytical potential of communicational doxa is strongest when implemented in relation to fields, because it can then be linked to a certain "game," where a certain type of capital is at stake. This is the meaning I will ascribe to doxa as we now turn to the empirical part of this article. Here, I will attempt to address a twofold question that has been left unanswered so far. It concerns how mediatization moulds and is moulded by doxa, and how these dynamics are related to the sense of autonomy among agents. Ultimately, my study (and the suggested approach) may shed light on one of Couldry's (2014) key concerns, namely how mediatization potentially transforms the limits and logics of fields. However, here I approach such changes "from below," i.e., from the viewpoint of everyday practices and materialites, rather than from above.

\section{Case study: The mediatized doxa of UN organizations}

Within an ongoing research project, Kinetic Élites: The Mediatization of Social Belonging and Close Relationships among Mobile Class Fractions (funded by the Swedish Research Council), qualitative fieldwork has been carried out in three social fields: the academic field, the field of corporate business, and the field of international politics, development and diplomacy (largely converging with the United Nations). The aim of the project is to unveil the significance of media in general, and new media in particular, for maintaining social bonds with friends, family and other close relations under conditions of high mobility. It means that the project investigates mobile class fractions within the dominant classes, i.e., agents occupying or aspiring to status positions within their fields, whose occupations necessitate spending a large amount of time on the move or staying longer periods abroad (with or without accompanying family members). Even though the prime focus is on close relationships, the data also cover questions related to the field in order to estimate how the logics of different fields spill over onto the realms of private life, to what extent, and what differences the media make in such processes.

In this article I draw on findings from the study of UN employees, based on interviews, discussions and observations I conducted in Geneva during two periods of fieldwork: five weeks in May-June 2014 and one week in October 2014. The data include 14 interviews with highly skilled Scandinavian expatriates currently, or until recently, employed by international organizations based in Geneva: the ILO, UNHCR, UNAIDS, OCHA, APT and Global Fund. The majority of the informants are women aged between 35 and 50, whereas the total age-span ranges from approximately 30-65 years. Whilst these biases should be kept in mind, they are unlikely to have any significant implications for the principal and theoretical arguments I want to put forward in this article. All interviews were conducted on-site in Geneva, in most cases at the interviewee's work place, except for two that were conducted via Skype. The interview recordings are between 50 and 120 minutes long (75 minutes on average). In the following transcriptions, all informants are anonymous, and I have refrained from mentioning which organizations they work for. 
A key point of departure is that I identify my interviewees as agents within a particular field. I will label this the "field of UN organizations," which is to be considered a tentative definition. The exact limits of the field are not possible to delineate based on the current sample, which also includes a few representatives of non-UN organizations. However, this study, together with previous research (Jansson, 2011, 2013b), suggests that it is reasonable to treat the international arena of development organizations, NGOs, and diplomatic institutions, as a rather distinct field that legitimates certain forms of competences and skills (as capital) and sanctions certain types of (international) backgrounds and trajectories. Of particular importance, besides formal education and international degrees, are the experiences of working in a variety of international settings, and having acquired both an international network and competences of cultural adaptability (through, for example, language and cultural skills) (ibid.). The "field of UN organizations" should then perhaps best be understood as a sub-field within a broader field of international politics, development and diplomacy.

In the following, I make two inter-connected points. Firstly, I show that mediatization implicates a tacit adherence to the spatial and temporal expansion of doxa. The affordances of mobile transmedia technologies reverberate with the doxic demands of mobility and availability, implying that doxa mixes with the time-spaces of private life. Secondly, I argue that the adherence to these communicational demands becomes an unspoken precondition for further trajectories within the field, whereas the mastery of new media (as such) cannot be seen as a form of capital.

\section{Mediatization and the osmotic expansion of doxa}

The limits of the field are situated at the point where the effects of the field cease. (Bourdieu, in Bourdieu and Wacquant, 1992: 100)

Digital media occupy a ubiquitous yet rather mysterious position in the lives of my informants. In certain respects, media even belong to a "technological unconscious" (Amin and Thrift, 2002), especially when it comes to the seemingly natural ways in which they have, as a matter of routine, started crisscrossing the lines between private and professional realms. Many of the directors, experts and technical officers that I have interviewed are used to an almost overwhelming amount of job-related emails, which cannot always be handled during regular working hours. This is combined with implicit organizational expectations on their availability, including when formally off-duty. They also speak of an organizational culture where it is common to copy a large number of colleagues into email conversations, in order to ensure certain measures are being documented and seen by the right persons, and avoid the risk that anybody feels side-stepped. Linn, who works as technical officer, explains: 
If there is a report I have to submit then I also have to copy $x, y$ and $z$, so that I'm covered kind of, so there isn't anybody responsible for an area you were not aware of who becomes upset or sends an angry email back to you with copy to the highest director... So it's used for marking territories of course. And if you look at the level of the departmental director, he or she probably receives two hundred emails every day - enormous amounts... and it's very difficult to change even though you might try.

These types of normalized and routine procedures, established during the era of stationary computers, are part of communicational doxa and are today, somewhat paradoxically, reinforced by the spread of personal mobile technologies. Smartphones in particular make it also possible to handle email flows when on the move or at home. In the organizations I have visited, however, only directors at higher levels are entitled to such technologies by their employer, which means that doxa has successively come to involve an implicit material demand on agents to appropriate and use personal technologies for carrying out work related communication. As Leena, a technical officer in her early 30s puts it, "when I worked in Zambia I had a Blackberry but not here, don't ask me why [...] but I'm expected to be reachable via my phone, which is my phone."

This osmotic situation is not a unique feature of the UN field, of course. Still, there are certain conditions that make the boundaries of professional life more permeable here than in most other parts of society. Most importantly, the geographically mobile nature of these professions and social trajectories, brings along a heightened ritual dependence on various means of interpersonal communication. As Elliot and Urry (2010) note, digital devices come to work as a kind of mobile depository of emotion, which lower the social and emotional costs of travelling lifestyles. Furthermore, the lowered economic costs for staying in touch with friends and family in one's homeland and elsewhere (a key aspect of polymedia, see Madianou and Miller (2012)), lead to a radically broadened scope of media choice, and more flexible interaction rituals. Many of my informants point to this lowered techno-economic threshold as the single most important change regarding their working conditions during the last decade. Peter, who works as a portfolio manager, describes how he nowadays uses his commuting time in Geneva for contacting friends in other parts of the world:

One important change is the costs and the barriers that there used to be for making phonecalls from a mobile, the more those costs are going down the lower the barriers become, and it's much easier for me to keep in touch. It's always easier to call from the mobile than waiting until you get home in order to make a Skype-call or call someone from a landline connection. [...] When I drive home from work, that's when I call my friends most of time, in Sweden or wherever... That's when I feel that I have that time and I'm not doing something else or there are other things going on just around me. When I'm at home it's more difficult. [...] In the car, I just give a call to people I come to think of in the moment. That's how it works. 
This example highlights a sense of growing individual autonomy, a possibility to establish a genuinely glocal communicative space in the interstices of everyday textures, where media practices amalgamate with other routines. Other informants tell similar stories, pinpointing a number of different channels and applications. Notably, instant messaging systems such as WhatsApp have, in some cases, been introduced by the interviewees' children, and then appropriated as increasingly indispensable technics for communication and coordination among family members as well as close friends.

This is also the point where potentially growing autonomy runs the risk of abolishing the barriers to work-related communication, leading to the integration of applications like WhatsApp as part of communicational doxa. Whereas email and Skype are the predominant means of communication within the UN doxa, WhatsApp and other social media provide opportunities for extending the reach of doxa, and keeping agents in their place. Leena describes a situation where her boss used WhatsApp for overcoming a spatio-temporal gap in communication:

\footnotetext{
So he wrote to me on WhatsApp during lunch, which is actually leisure-time, "Where are you and when are you coming back?" and I answered that, "I'll be back in ten minutes," and then went directly to him and wrote that, "I'm here now"... But I hadn't read, he had sent me an email during the lunch-break, which I hadn't read, and I just went straight to him and said, "I'm here now, what do you want to talk about?" and he said "Ah, didn't you read my email?"
}

The important thing to note here is that there are no formal discussions or decisions taking place as to what media access should be expected from colleagues, and in what ways certain media should be used. Rather, new media are entering the realm of communicational doxa through processes of social transaction, supported by other unspoken dictums of the UN doxa, notably the demand on being flexible, available and ready to move. In effect, we may speak of mutual osmotic pressures between doxa and everyday processes of mediatization.

There are of course variations depending on organization and the position of agents. In general, however, the field of UN organizations is marked by adherence to the rules of more or less permanent mobility. This regards both the demands on work-related travel that is associated with many positions, and the expectations on building professional biographies that include a certain mix of stationings around the world. Along with these demands come certain functional requirements regarding the use of media technics. In other words, the rules of the game are such, that disobedience to communicational doxa and the questioning of certain means of communication always involves a risk, whereas the possession of private media devices per se does not count as capital.

Ruben, who is in his early 60s and works as an expert, used to travel a lot earlier in his career. During the 1990s he travelled about 100 days every year and visited 60 countries. More recently, however, he has come to experience his life being more comfortable without travelling, and has not aimed for higher positions or new stationings. One reason 
for his "travelling fatigue," is the growing pressure on being constantly available, including while being away, and the increasingly boundless spaces of work that emerge due to new forms of communication. Furthermore, the organization he works for does not provide the mobile technologies that he is expected to use.

When I started travelling in 1989 travelling was much more pleasurable. In 1989 we made a programme via letter-writing or using telex, and then there were always a few meetings that actually didn't take place, and in the evenings I was free, didn't have any mobile, no laptop. If I was away for two weeks I phoned the office perhaps once a week asking if everything was ok. But now, one is expected to do the same work while travelling as one would have done if still in the office. That's a bit strange...

Ruben's adjustment of his professional trajectory can be seen as an expression of transactional media dependence, but in a negative sense, meaning that he has decided to find ways of not submitting to communicational doxa, in order to maintain a higher degree of autonomy as an individual. He has thus actively sought out the limits of the field, at the price of losing a certain degree of autonomy as an agent, and diminishing his chances of gaining more capital (which he is fully aware of after having worked many years within the field). Similar tactics of resistance can be discerned among other informants, especially those who try to combine family life with a professional career. Since these agents have not been in the field as long as Ruben, however, they do not express the same willingness to take risks. Linn, for example, is actively trying to find alternatives to travelling, but without jeopardizing any opportunities for further advancement. As she argues, she wants there to be a positive recognition of agency which is also related to sometimes saying 'no' to offers.

The tactics of Linn and Ruben can be seen as heterodoxic agency, which might play a role in the long-term development of the field. What is important to note here, however, is that these battles do not question the basic rules of the game. The fact remains that continuous mobility and the further gaining of international experience are the key resources of capital accumulation. Media related skills and resources attain a ubiquitous status within these battles, continuously playing into the regimes of communicational doxa, but should be understood primarily as undercurrents that shape the material and symbolic conditions of these battles.

\section{Conclusion}

In this article I have introduced a Bourdieusian approach to mediatization. I have argued that the Bourdieusian framework can make valuable contributions to a critical perspective on mediatization, one that moves beyond the divides between institutionalist, social-constructivist and materialist understandings of mediatization. At the core of such a critical view, is a concern with how mediatization affects relations of autonomy and dependence. In other words, it is a concern with the processes of naturalization through which media 
technologies and various institutionalized forms of mediation achieve the status of indispensable parts of, or conditions for, social practice. In Bourdieusian terms, this happens when media become integrated within doxa in the shape of taken for granted technics, properties and/or textures. In this article, I have introduced the concept of "communicational doxa" as a sub-category of doxa. The notion of communicational doxa, I argue, helps us understand how various forms of media dependence, and therefore limitations of autonomy, evolve as part of a much broader submission to social and cultural restraints. These are the restraints that agents put their belief into, precisely because the maintenance of these structures is the prerequisite for being recognized as a member of the field.

I have also tried to illustrate how communicational doxa can be applied as an analytical concept for concrete studies of mediatization processes within social fields. My study of the field of UN organizations (carried out in Geneva) has exposed a social phenomenon that can be described as "osmotic pressures." What I mean by this, is that the ubiquitous nature of new media makes them highly absorbable by communicational doxa, while at the same time contributing to the expansion of doxa beyond its earlier confines and into the realm of private life. The findings from this analysis strongly reflect those from other studies of the (trans)mediatization of social life. Still, these findings should at this stage be taken as a preliminary sketch of the field in question. The value attached to continuous geographical mobility within the doxa of UN organizations is a key condition that clearly shapes the ways in which mediatization unfolds in this study, giving shape to contextually specific relations of functional, transactional and ritual dependences. In future studies we need to make comparisons between fields, and look more closely at the significance of various textural conditions within fields in order to further validate and refine the conceptual framework introduced here.

I want to end this article with an important epistemological point regarding the relationship between communicational doxa and the notion of media meta-capital (Couldry, 2014). The approach I have advanced here should be seen not as a dismissal of Couldry's points, but as a request to (a) conceive of media (and thus mediatization) as much more than just (the adaptation to) institutions of symbolic power, and (b) to engage in a Bourdieusian epistemic translation, that more sufficiently accounts for the phenomenological traits (and problems) of his theory (cf. Myles, 2004). As Couldry (2014) argues, the idea of media meta-capital opens up avenues for linking mediatization to broader strands of social theory, especially regarding structural transformations within politics and economy, for example. However, it is only when we account for the more mundane power of communicational doxa, the interplay between functional, transactional and ritual dependences, that we will be able to see how mediatization is socially realized and shaped through embodied practice. 


\section{References}

Amin, A. \& Thrift, N. (2007). 'Cultural-economy and cities,' Progress in Human Geography, 31(2), pp. 143-161. Andrejevic, M. (2014). 'The infinite debt of surveillance in the digital economy'. In Jansson, A. \& Christensen, M. (Eds.) Media, Surveillance and Identity: Social Perspectives. New York: Peter Lang.

Bourdieu, P. (1972/1977). Outline of a Theory of Practice. Cambridge: Cambridge University Press.

Bourdieu, P. (1979/1984). Distinction: A Social Critique of the Judgment of Taste. London: Routledge.

Bourdieu, P. (1996). The State Nobility. Cambridge: Polity Press.

Bourdieu, P. (1997/2000). Pascalian Meditations. London: Polity Press.

Bourdieu, P. \& Wacquant, L.J.D. (1992). An Invitation to Reflexive Sociology. Chicago: The University of Chicago Press.

Couldry, N. (2003a). 'Media meta-capital: extending the range of Bourdieu's field theory'. Theory and Society 32 (5-6), pp. 653-77.

Couldry, N. (2003b) Media Rituals: A Critical Approach. London: Routledge.

Couldry, N. (2014) Mediatization and the future of field theory. In Lundby, K. (Ed.) Mediatization of Communication: Handbooks of Communication Science, Vol. 21. Berlin: De Gruyter Mouton.

Couldry, N. \& Hepp, A. (2013). 'Conceptualizing mediatization: Contexts, traditions, arguments'. Communication Theory 13(3), pp. 191-202.

Elliott, A. \& Urry, J. (2010). Mobile Lives. London, New York: Routledge.

Giddens, A. (1991). Modernity and Self-Identity: Self and Society in the Late Modern Age. Cambridge: Polity Press.

Goffman, E. (1959). The Presentation of Self in Everyday Life. Harmondsworth: Penguin.

Ihde, D. (1990). Technology and the Lifeworld: From Garden to Earth. Bloomington, Minneapolis: Indiana University Press.

Hartmann, M. (2006). 'The triple articulation of ICTs: Media as technological objects, symbolic environments and individual texts'. In Berker, T.M. Hartmann, Y. Punie \& K.J. Ward (Eds.) The Domestication of Media and Technology (pp. 80-102). Maidenhead: Open University Press.

Hepp, A. (2012). 'Mediatization and the 'moulding force' of the media'. Communications 37(1), pp. 1-28.

Hjarvard, S. (2014). 'Mediatization and cultural and social change: an institutional perspective'. In Lundby, K. (Ed.) Mediatization of Communication: Handbooks of Communication Science, Vol. 21. Berlin: De Gruyter Mouton.

Ihlen, Ø. \& Pallas, J. (2014). 'Mediatization of corporations'. In Lundby, K. (Ed.) Mediatization of Communication: Handbooks of Communication Science, Vol. 21. Berlin: De Gruyter Mouton.

Innis, H. (1951). The Bias of Communication. Toronto: University of Toronto Press.

Jansson, A. (forthcoming).' The moulding of mediatization: The stratified indispensability of media in close relationships', Communications: The European Journal of Communication Research.

Jansson, A. (2014). 'Indispensible things: On mediatization, space and materiality'. In Lundby, K. (Ed.) Mediatization of Communication (Handbook of Communication Sciences, Vol 21). Berlin: De Gruyter Mouton. Jansson, A. (2013a). 'Mediatization and social space: Reconstructing mediatization for the transmedia age', Communication Theory 23(3), pp. 279-96.

Jansson, A. (2013b). 'A second birth? Cosmopolitan media ethnography and Bourdieu's reflexive sociology', International Journal of Cultural Studies, 16(2), pp. 135-50.

Jansson, A. (2011). 'Cosmopolitan capsules: Mediated networking and social control in expatriate spaces'. In Christensen, M.; Jansson, A. \& Christensen, C. (Eds.) Online Territories: Globalization, Mediated Practice and Social Space. New York: Peter Lang.

Kitchin, R. \& Dodge, M. (2011). Code/Space: Software and everyday life. Cambridge, MA: MIT Press. 
Krotz, F. (2007). 'The meta-process of 'mediatization' as a conceptual frame'. Global Media and Communication 3(3), pp. 256-260.

Livingstone, S. (2007). 'On the material and the symbolic: Silverstone's double articulation of research traditions in new media studies', New Media and Society 9(1), pp. 16-24.

Lundby, K. (2014). 'Mediatization of Communication'. In Lundby, K. (Ed.) Mediatization of Communication: Handbooks of Communication Science, Vol. 21. Berlin: De Gruyter Mouton.

Lövheim, M. (2014). 'Mediatization and religion'. In Lundby, K. (Ed.) Mediatization of Communication: Handbooks of Communication Science, Vol. 21. Berlin: De Gruyter Mouton.

Madianou, M. \& Miller, D. (2012). Migration and New Media: Transnational Families and Polymedia. London: Routledge.

McLuhan, M. (1964). Understanding Media: The Extensions of Man. New York: McGraw-Hill.

Moores, S. (2012). Media, Place and Mobility. Palgrave Macmillan.

Morley, D. (2009). 'For a Materialist Non-Media-Centric Media Studies', Television and New Media 10(1), pp. 114-6.

Myles, J.F. (2004). 'From doxa to experience: Issues in Bourdieu's adoption of Husserlian phenomenology', Theory, Culture and Society 21(2), pp. 91-107.

Rawolle, S. \& Lingard, B. (2010). 'The mediatization of the knowledge based economy: An Australian field based account'. Communications: The European Journal of Communication Research 35(3), pp. 269-86.

Rawolle, S. \& Lingard, B. (2014). 'Mediatization and education: A sociological account'. In Lundby, K. (Ed.) Mediatization of Communication: Handbooks of Communication Science, Vol. 21. Berlin: De Gruyter Mouton.

Schulz, W. (2004). 'Reconstructing mediatization as an analytical concept'. European Journal of Communication 19 (1), pp. 87-101.

Schutz, A. (1962). Collected Papers, Vol 1: The Problem of Social Reality. The Hague: Martinus Nijhoff.

Schutz, A. \& Luckmann, T. (1973). The Structures of the Life-World. Evanston: Northwestern University Press. Silverstone, R. (1994). Television and Everyday Life. London: Routledge.

Strömbäck, J. \& Esser, F. (2014). 'Mediatization of politics: transforming democracies and reshaping politics'. In Lundby, K. (Ed.) Mediatization of Communication: Handbooks of Communication Science, Vol. 21. Berlin: De Gruyter Mouton.

Williams, R. (1974). Television: Technology and Cultural Form. London: Fontana.

André Jansson

Ph.D., Professor

Department of Geography, Media and Communication

Karlstad University, Sweden

andre.jansson@kau.se 